Received: $2020-05-18$

\title{
Effect of different drying processes on an antioxidant potential of three species of the Lamiaceae family
}

\author{
IZABELLA KWAŚNIEWSKA-KAROLAK*®, RADOSŁAW MOSTOWSKI®
}

Faculty of Biotechnology and Food Sciences

Łódź University of Technology

Stefanowskiego 4/10

90-924 Łódź, Poland

*corresponding author: e-mail: izabella.kwasniewska-karolak@p.lodz.pl

\section{Summary}

Introduction: Spice plants are a rich source of biologically active compounds. Processes of drying, limits the development of microorganisms and biochemical reactions in raw herbs, at the same time modifies their chemical composition.

Objective: The aim of this work was to evaluate the effect of drying process of selected plants on their antioxidant potential and the content of biologically active compounds.

Methods: The herbal materials thyme herb (Thymus vulgaris L.), sage leaves (Salvia officinalis L.) and rosemary leaves (Rosmarinus officinalis) were dried using two methods: convective (at $30^{\circ} \mathrm{C}$ ), and freeze-drying. In both, fresh and subjected to drying processes herbs, changes in total polyphenol and antioxidant potential (with the DPPH radical), vitamin C (in the form of ascorbic acid) and chlorophyll pigments contents, were studied.

Results: The highest content of polyphenols and vitamin $\mathrm{C}$ was recorded in rosemary, while sage was characterized by the highest content of chlorophylls. It was found that the drying processes caused large losses of vitamin $\mathrm{C}$ (ascorbic acid) and dyes in comparison to the fresh material. The highest losses of vitamin $\mathrm{C}$ occurred in convection dried sage (95\%), while most was preserved in lyophilised thyme (losses 74\%). Drying had also influenced the reduction of the content of chlorophylls with the largest loss of these compounds, at $94 \%$ observed in the freeze-dried rosemary. However, the content of polyphenols increased, underscoring a large impact on the antioxidant activity of herbs.

Conclusions: Drying processes resulted in the release of phenolic compounds, so their content increased three to four times in the case of rosemary and sage. The largest increase was observed in the case of lyophilised thyme. Simultaneously, the antioxidant potential was significantly increased. Herbal droughts proved to be a rich source of antioxidant compounds with promising applications as a food additive.

Key words: drying, herbs, antioxidant activity, ascorbic acid, chlorophyll

Słowa kluczowe: suszenie, zioła, działanie antyoksydacyjne, kwas askorbinowy, chlorofil 


\section{INTRODUCTION}

The renewed interest in nutrition has contributed to the reintroduction of herbs used in various forms. As a single component or combination, fresh or dried, herbs are a common element of the daily diet.

Plants have always fascinated people. Paracelsus, a German physician, alchemist, and naturalist, said that forests and meadows conceal real healing treasures. Such a statement was formed on the basis of human experience over the centuries. Due to the high content of active substances, herbs have found wide range of applications - not only in the food industry, but also in medicine and pharmaceutical industries. Spice plants are rich in essential oils, alkaloids, tannins, glycosides, vitamins, mineral salts, and phenolic compounds, which are natural antioxidants. Spices also have an anti-bactericidal and immunizing effect, they can lower blood pressure and stimulate the secretion of stomach acid and facilitate the absorption of nutrients $[1,2]$.

To preserve spice plants, few different methods are used. Drying is one of the oldest methods of food preservation. It involves dehydrating in order to inhibit the chemical reactions and physical changes in the material. It also limits the development of microorganisms, resulting in longer storage period and the usefulness of the product for consumption $[3,4]$.

Three types of spice herbs: rosemary, sage and thyme were tested. Rosemary (Rosmarinus officinalis) is an evergreen, aromatic shrub that grows wild in whole Mediterranean region alongside with melissa, sage, lavender, thyme, and juniper. The raw material used for food purposes are rosemary leaves and herb (Herba et Folium Rosmarini). The herb contains tannins (5-8\%), essential oil (1-2.5\%), ferulic acid $(10.0-11.0 \mathrm{mg} / \mathrm{g})$, rosmarinic acid $(1.2 \mathrm{mg} / \mathrm{g})$, caffeic acid (0.1-0.2 mg/g) and chlorogenic acid. Also diterpenes, such as carnosic acid or carnosol, and triterpenes (oleanolic acid, ursolic acid, $\alpha$-amirin, $\beta$-amirin, and betulin are included. Other active compounds are picrosalvin (up to $4.6 \%$ ), rosmadial, rosmanol, flavonoids (apigenin, luteolin, diosmetin, hesperin) and phytosterols. The essential oil consists of 1,8-cineol (17-55\%), camphor (10-25\%), borneol (8-20\%) and its esters (2-7\%), pinene (15-25\%), terpineol (about 12\%), camphene (about 5\%), verbenone $(1-8 \%)$, as well as $p$-cymene, linalool, geraniol, eugenol, carvacrol and piperitone [5].

Rosemary is one of the plants with the strongest antioxidant effect. It owes its ability to chelate metals and prevent the formation of free radicals, transforming them into less active forms. Extracts and essential oils of rosemary are used as additives in fats and oils. It also has antibacterial and antifungal properties. Due to its health-promoting properties, rosemary is often used both in kitchen and for its health properties. The herb is commonly used for skin diseases, such as dermatitis and seborrheic eczema. Rosemary is known to inhibit the growth of microorganisms that cause tooth decay. It stimulates the secretion of digestive juices, increases appetite and digestion, increasing bile production. Herb has a beneficial effect on the nervous system, relieves tension and general exhaustion. Its alcohol and hydro-alcoholic extracts lower blood pressure and improve circulation $[2,5]$.

Sage (Salvia officinalis L.) is a semi-bush of the Labiatae family from the Mediterranean region. The name of the plant comes from the words salvare (Latin: cure) and officina (Latin: pharmacy). The raw herb is a sage leaf (Folium Salviae) and sometimes herb sage (Herba Salviae). Both raw materials contain the same active compounds, but in different amounts. The most important component is essential oil in an amount up to $2.5 \%$, containing mainly $\alpha$ - and $\beta$-thujone (up to 50\%), 1,8-cineol (up to $15 \%)$, camphor, other terpenes such as: borneol or pinene, and sesquiterpenes. In addition to the oil, the raw material also contains catechin tannins (8-13\%), multi-phenolic acids such as caffeic and chlorogenic, triterpene saponins (ursolic acid, oleanolic acid), bitter compounds (picrosalvin), tannins (3-8\%), undetermined estrogenic compound and antiperspirant, and mineral salts. It is rich in vitamin $\mathrm{B}_{1}$ (about $850 \mathrm{mg} \%$ ), PP, carotene (vitamin A) and vitamin C (420 mg\%) $[6,7]$. Due to its anti-inflammatory, astringent and antibacterial properties, it is used in prevention and treatment of many diseases. It is considered to be the strongest plant antiperspirant. The sage extract has many uses in everyday life. It inhibits the growth of saprophytic bacterial flora, prevents excessive intestinal fermentation and helps food digestion. Infusions are used for rinsing in inflammatory mucous membranes and catarrh of the mouth, gums and throat, and externally in skin ailments, such as blemishes, skin abrasions, minor cuts, and boils [6].

Thyme (Thymus vulgaris L.), known as thyme thyme, Italian thyme, garden thyme is a plant belonging to the labial family. The raw material is thyme herb - Herba Thymi. Plant contains essential oil in an amount of up to 3.5\%. Most volatile compounds are present in the oil belong to the group of monoterpenes, which include thymol (30-55\%). It is responsible for a strong, sharp smell of thyme. This group also includes: carvacrol (1-5\%), which is 
the thymol isomer as well as $p$-cymene $(15-20 \%)$ or $\beta$-terpinene (5-10\%). There are also methyl ethers of thymol and carvacrol. Other monoterpenes are: linalool (1-5\%), borneol, camphor, limonene, myrcene, $\beta$-pinene, trans-sabinen hydrate, $\alpha$-terpineol and terpinene-4-ol. Among the sesquiterpenes, $\beta$-caryophyllene (1-3\%) can be mentioned. In addition, tannins (up to 10\%), triterpene compounds including oleanolic and ursolic acid, polyphenolic acids (caffeic and chlorogenic acid), flavonoids (lutein and apigenin and their glycosides), saponins, bitter and mineral salts were found in the herb, with a significant amount of lithium $[7,8]$.

Thyme has many uses due to its antioxidant potential and chemical composition. Extract from the herb is used as an expectorant and cough-relieving agent, as it increases the spontaneous movement of upper respiratory tract, as well as increases mucus secretion, thins secretion in the throat and makes it easier to expectorate. Active phenolic compounds such as thymol and carvacrol show a bactericidal effect, especially against oral and pharyngeal streptococci. Thyme improves digestion, thanks to the ability to stimulate the secretion of gastric juice by the bitter compounds. It is used externally to wash wounds, because of antiinflammatory and antiseptic properties [7].

The contents of vitamins and other biologically active compounds in processed foods are important features of their quality and nutritional value, as well as the accuracy of technological processes. The issue of antioxidant properties of dried products is rarely discussed in the scientific literature [9]. Studies on changes in the antiradical activity of dried plant tissue are interesting due to the ambiguous nature of these changes. On the one hand, high temperature and dehydration lead to the degradation of compounds with antiradical properties. On the other hand, the products of enzymatic and non-enzymatic browning reactions, formed during drying, may have the character of antioxidants [10]. Previous studies on changes in the quality of plant products, subjected to drying, indicate decrease in vitamin $\mathrm{C}$ and chlorophylls [11-14]. However, trends in polyphenols content changes are not clear. Depending on the applied parameters of the drying processes, both an increase and decrease in their content in the dried products were observed [15-17].

Due to above and a number of health-promoting properties, the research was undertaken to determine the antioxidant properties of herbal material described, both fresh and dried. The aim of this work was to evaluate the effect of drying process of selected plants on their antioxidant potential and the content of biologically active compounds. Two methods of drying were used: convection and sublimation.

\section{MATERIAL AND METHODS}

\section{Plant material and experimental design}

the examined material was herb leaves in different forms - fresh and dried rosemary, sage and thyme. The tested herbs were subjected to convection drying [3] and freeze-drying [19]. Herbs used in this investigation were purchased from a local market in the city of Łodź, Poland.

Food drier (Niewiadów type 970 PS) was used for convection drying. Drying time was determined experimentally. A portion of $30 \mathrm{~g}$ of herbs was dried to a constant weight for 4 hours. Convection drying is a method commonly used in an industrial scale. The heat was supplied to the material via a drying medium-air, and the key parameter of this process was temperature $\left(30^{\circ} \mathrm{C}\right)$. Inadequate drying temperature can cause undesirable changes in the sensory profile of spices and losses of thermo-labile compounds, which results from the high sensitivity of these substances to the destructive effects of elevated temperature. Disadvantages of this method are physicochemical changes, which lead to a decrease in the quality of the raw material $[20,21]$.

Freeze drying was carried out in a CHRIST DELTA 1-24 LSC freeze dryer in the following three steps: sample freezing at $-50^{\circ} \mathrm{C}$ for $24 \mathrm{~h}$, drying at $20^{\circ} \mathrm{C}$ at $0.42 \mathrm{mBar}$ for $20 \mathrm{~h}$ and drying at $20^{\circ} \mathrm{C}$ under $0.032 \mathrm{mBar}$ for $4 \mathrm{~h}$. Immediately after drying, herbs were packed in vacuum sealed packages. Freezedrying is a process involving the removal of water from a frozen product as a result of sublimation of ice. During this process, most biochemical and microbiological reactions are inhibited, which allows maintaining the high quality and the durability of material [12]. The advantage is also the preservation of the raw materials characteristics, i.e. shape, consistency, aroma, colour and nutrients. In addition, freeze-drying allows reducing the weight of the product and eliminates the cold chain [23].

\section{Analytical methods}

Both in fresh and dried material, dry mass content was determined by the gravimetric method [24], the antioxidant potential (sums of polyphenols) by the Folin-Ciocalteu method [25], antioxidant activity 
with radical DPPH by Yen and Chen method [26], $\mathrm{L}$-ascorbic acid content was determined by the Tillmans method [27] and content of chlorophyll dyes by the Vernon method [28].

Preparation of the extract for the determination of polyphenol content and testing for antioxidant activity were prepared as follows: $0.2 \mathrm{~g}$ dried or $4 \mathrm{~g}$ fresh plant was weighed into a ground flask, $20 \mathrm{~cm}^{3}$ of $70 \%$ methyl alcohol was added and extraction was carried out. The extraction was performed for 1 hour at $22^{\circ} \mathrm{C}$. Then, the solution was filtered through a fluted filter. The filtrate was the material for further analysis. The antioxidant activities of the ethanol herbs extracts were measured using the stable DPPH radical (Sigma Aldrich).

\section{Preparation of the standard curve for total poly- phenol content}

Catechin standard solution (Sigma Aldrich) in a volume of $0.1 ; 0.25 ; 0.5 ; 1.0 ; 2.0 ; 4.0 ; 8.0 \mathrm{~cm}^{3}$ with a concentration of $100 \mu \mathrm{g} / \mathrm{cm}^{3}$, was mixed with $2 \mathrm{~cm}^{3}$ of the Folin-Ciocalteu reagent (Chempur) and $10 \mathrm{~cm}^{3}$ of distilled water. Samples were incubated for 5 minutes. Then, $4 \mathrm{~cm}^{3}$ of a $10 \%$ sodium carbonate solution was added, made up to $50 \mathrm{~cm}^{3}$ with distilled water, mixed and incubated in the dark for $1 \mathrm{~h}$. For the determination of the standard curve, the absorbance was measured at a wavelength of $\lambda=750 \mathrm{~nm}$. Distilled water was used as a reference. The curve was determined as follows: $\mathrm{y}=1.0526 \mathrm{x}+0.0778, \mathrm{r}^{2}=0.9946$.

\section{Antioxidant activity measurement}

Basic plant extracts in a volume of $0.1,0.2,0.3,0.4$, $0.5 \mathrm{~cm}^{3}$ were mixed with $1 \mathrm{~cm}^{3}$ of DPPH solution $\left(0.0096 \mathrm{~g} / 50 \mathrm{~cm}^{3}\right.$ in $100 \%$ methanol $)$ and made up to $5 \mathrm{~cm}^{3}$ with $70 \%$ methanol. At the same time, a control test was prepared: $1 \mathrm{~cm}^{3}$ of DPPH was mixed with $2 \mathrm{~cm}^{3}$ distilled water and $3 \mathrm{~cm}^{3}$ of $70 \%$ methanol. After mixing, all samples were incubated in the dark for 30 min. Thereafter, the absorbance of the samples at $517 \mathrm{~nm}$ was measured using a T60 VIS spectrophotometer.

The antioxidant activity was determined by the formula:

$$
\text { reduction of DPPH radical [\%] }=\frac{A_{0}-A_{E}}{A_{0}} 100 \% \text {, }
$$

where:

$A_{E}$ - absorbance of the tested sample,

$A_{0}$ - absorbance of the control sample.
After calculation of the antioxidant activity of the extracts, the dependence of the degree of DPPH reduction on the concentration of antioxidants in the extracts was determined. Then, the dose of the extract $\left(\mathrm{IC}_{50}\right)$ resulting in a $50 \%$ reduction of $\mathrm{DPPH}$ under the conditions of the experiment was calculated.

Determination of ascorbic acid content consists of titrating the L-ascorbic acid solution with Tillmans reagent (Chempur), until a light pink colour appeared [27]. Five grams of ground fresh material or $2 \mathrm{~g}$ of dried material wase measured into a ground flask and combined with $125 \mathrm{~cm}^{3}$ of $2 \%$ oxalic acid. The solution was filtered through a fluted filter. $10 \mathrm{~cm}^{3}$ of the extract was measured into a $200 \mathrm{~cm}^{3}$ conical flask. Then, $20 \mathrm{~cm}^{3}$ of $2 \%$ oxalic acid was added and titrated with Tillmans's reagent, stirring quickly, until a slightly pink colour appeared, not disappearing within 30 seconds.

The AA (ascorbic acid) content was calculated from the formula:

$$
A A=\frac{\left(V-V_{0}\right) \times m_{o t}}{V c \times a}[g / 100 g]
$$

where:

$\mathrm{V}$ - the volume of OT used for titration of the AA extract, $\mathrm{cm}^{3}$,

$\mathrm{V}_{0}$ - OT volume used for titration of the blank, $\mathrm{cm}^{3}$, $\mathrm{M}_{\text {OT }}$ - OT titer, mg AA / $\mathrm{cm}^{3} \mathrm{OT}$,

$\mathrm{V}_{\mathrm{C}}$ - volume of AA extract taken for titration, $\mathrm{cm}^{3}$, $\mathrm{a}$ - mass of the sample in $1 \mathrm{~cm}^{3}$ of the extract, $\mathrm{g}$.

The method of dye determination consists in determining the content of chlorophyll a $(\mathrm{Ca})$, chlorophyll b $(\mathrm{Cb})$ and total chlorophylls (TC) on the basis of extract absorbance measurements at $649 \mathrm{~nm}, 665 \mathrm{~nm}$ [28]. $1 \mathrm{~g}$ of product was weighed and quantitatively transferred to a flask and homogenized with $50 \mathrm{~cm}^{3}$ of anhydrous acetone. The homogenate was filtered through a fluted filter. Then $0.75 \mathrm{~cm}^{3}$ of $80 \%$ acetone solution was transferred to a $25 \mathrm{~cm}^{3}$ flask and made up to the mark with dye extract (control sample). The converted sample was prepared in a similar way except the same amount of saturated oxalic acid was added instead of $0.75 \mathrm{~cm}^{3}$ of an $80 \%$ acetone solution. Samples were incubated in the dark for 2 hours. After this time absorbance was measured using a T60 VIS spectrophotometer. 
The content of chlorophylls was calculated from the formulas:

$$
\begin{aligned}
& C a=11,63 A_{665}-2,39 A_{649}\left[\mathrm{mg} / \mathrm{dm}^{3}\right] \\
& C b=20,11 A_{649}-5,19 A_{665}\left[\mathrm{mg} / \mathrm{dm}^{3}\right] \\
& T C=6,49 A_{665}+17,72 A_{649}\left[\mathrm{mg} / \mathrm{dm}^{3}\right]
\end{aligned}
$$

where:

$\mathrm{A}_{649}$ - sample absorbance at $649 \mathrm{~nm}$,

$\mathrm{A}_{665}-$ sample absorbance at $665 \mathrm{~nm}$.

The obtained results were converted and presented in $\mathrm{mg} / 100 \mathrm{~g}$ d.m.

\section{Statistical calculations}

All measurements and analyses were carried out in triplicate. The data were presented as the means \pm standard deviations. The results were subjected to an analysis of variance in the two-way ANOVA using Statistica 7.1 software. Tukey's test was used to assess differences between means. The significance of differences was considered at the level of $p \leq 0.05$.

Ethical approval: The conducted research is not related to either human or animal use.

\section{RESULTS AND DISCUSSION}

The results of the content of the individual components, like dry mass, polyphenols, ascorbic acid and chlorophylls, in the tested herbal material were presented in tables $1-3$. The results of the tests showed a relationship between the chemical composition of the raw and dried herbal material and the herbal plant species.

The dry matter content of fresh herbal material ranged from 9.49 to $17.55 \%$, while in dried herbs it was $92.7-93.7 \%$. The differences between the water content in convective and sublimation droughts were small and did not exceed $0.5 \%$. The water content in the sublimation-dried thyme was the lowest among the tested herbs.

The content of the sum of polyphenolic compounds was determined by the Folin-Ciocalteu method. The F-C reagent, in addition to the colour reaction with polyphenols, also reacts with other components. It may cause that the sum of polyphenol compounds determined with the use of this method is higher than the real ones (tab. 1-3).
Conducted studies have shown that the content of total polyphenols depends on the herbaceous species. Among the examined herbs, the highest abundance in polyphenols was characterized by rosemary and the lowest by thyme.

The results of the conducted research indicate a significant influence of the applied processes on the quantity of released compounds, which determines antioxidant activity of herbs. The freeze-drying process caused the release of higher amounts of polyphenols, as compared to convective drying.

The graph shows the percentage of the increase in the content of polyphenolic compounds, in reference to fresh herbs for which the value of $100 \%$ was accepted.

In our research, the relationship between the polyphenol content and the antioxidant properties of fresh and dried herbs was demonstrated. In fresh rosemary, the $\mathrm{IC}_{50}$ value was $102.5 \mathrm{mg} / \mathrm{ml}$ (tab. 1) and was the highest among the tested herbs. For convective drought, the result was $7.50 \mathrm{mg} / \mathrm{ml}$, for freeze-dried $5.34 \mathrm{mg} / \mathrm{ml}$. The value of the $\mathrm{IC}_{50} \mathrm{co}$ efficient for thyme and its drought (convective and freeze-dried) was at the level of 98.5; 10.04 and $7.77 \mathrm{mg} / \mathrm{ml}$, respectively (tab. 3). Among the examined plants, the highest antioxidant activity was obtained for rosemary, and the lowest for thyme, both in fresh and dried form. According to research by Hossain et al. [15], the higher the polyphenol content is, the higher is the antioxidant capacity of plant.

On the basis of the obtained results it was found that freeze-dried showed greater scavenging capacity of free radicals than convective droughts. The values of the $\mathrm{IC}_{50}$ coefficient were compared and it was found that in the case of rosemary, 13 times less extract of convective drought and 19 times less extract of lyophilisate was needed, compared to fresh herbs, to sweep 50\% of free radicals. Regarding sage, it was calculated that 20 times less extract of convective drought and 34 times less extract from the lyophilisate was needed. Similarly, values for thyme indicated that 20 times less extract from convective drought and 25 times less extract from lyophilisate was needed to sweep the same amount of free radicals compared to fresh herbs.

During processing, food properties change, which has a significant impact on the quality of the final product. The processes carried out after the harvest of plants are of great importance because they directly affect the quality and quantity of active ingredients [29]. It is especially visible during drying, which causes changes in the content of bioactive compounds. 
Table 1.

The content of selected ingredients and antioxidant activity of fresh rosemary leaves and its droughts

\begin{tabular}{lccccc}
\hline & $\begin{array}{c}\text { Dry mass (d. m.) } \\
{[\%]}\end{array}$ & $\begin{array}{c}\text { Chlorophyll } \\
{[\mathrm{mg} / 100 \mathrm{~g} \mathrm{~d} . \mathrm{m} .]}\end{array}$ & $\begin{array}{c}\text { Polyphenols } \\
{[\mathrm{mg} / 100 \mathrm{~g} \mathrm{~d} . \mathrm{m} .]}\end{array}$ & $\begin{array}{c}\text { Ascorbic acid } \\
{[\mathrm{mg} / 100 \mathrm{~g} \mathrm{~d} . \mathrm{m} .]}\end{array}$ & $\begin{array}{c}\text { DPPH IC } \\
{[\mathrm{mg} / \mathrm{ml}]}\end{array}$ \\
\hline Fresh & $11.55^{\mathrm{a}} \pm 0.29$ & $396.35^{\mathrm{a}} \pm 20.65$ & $639.00^{\mathrm{a}} \pm 14.98$ & $55.26^{\mathrm{a}} \pm 1.56$ & $102.05^{\mathrm{a}} \pm 1.25$ \\
\hline Convective drought & $92.74^{\mathrm{b}} \pm 0.07$ & $205.67^{\mathrm{b}} \pm 15.09$ & $2019.00^{\mathrm{b}} \pm 31.58$ & $6.19^{\mathrm{b}} \pm 0.18$ & $7.50^{\mathrm{b}} \pm 0.54$ \\
\hline Freeze-drying & $92.96^{\mathrm{b}} \pm 0.14$ & $22.78^{\mathrm{c}} \pm 1.55$ & $2502.39^{\mathrm{c}} \pm 48.51$ & $11.37^{\mathrm{c}} \pm 0.37$ & $5.34^{\mathrm{c}} \pm 0.12$ \\
\hline
\end{tabular}

Results are means \pm standard deviation. Mean values in the same column designated with different small letters are significantly different $(\alpha=0.05)$

Table 2.

The content of selected ingredients and antioxidant activity of fresh sage leaves and its droughts

\begin{tabular}{lccccc}
\hline & Dry mass [\%] & $\begin{array}{c}\text { Chlorophyll } \\
{[\mathrm{mg} / 100 \mathrm{~g} \mathrm{~d} . \mathrm{m} .]}\end{array}$ & $\begin{array}{c}\text { Polyphenols } \\
{[\mathrm{mg} / 100 \mathrm{~g} \mathrm{~d} . \mathrm{m} .]}\end{array}$ & $\begin{array}{c}\text { Ascorbic acid } \\
{[\mathrm{mg} / 100 \mathrm{~g} \mathrm{~d} . \mathrm{m}]}\end{array}$ & $\begin{array}{c}\text { DPPH IC } \\
{[\mathrm{mg} / \mathrm{ml}]}\end{array}$ \\
\hline Fresh & $9.54^{\mathrm{a}} \pm 0.36$ & $766.37^{\mathrm{a}} \pm 30.90$ & $325.68^{\mathrm{a}} \pm 12.26$ & $31.53^{\mathrm{a}} \pm 1.85$ & $199.00^{\mathrm{a}} \pm 0.96$ \\
\hline Convective drought & $93.06^{\mathrm{b}} \pm 0.26$ & $381.52^{\mathrm{b}} \pm 25.56$ & $1159.79^{\mathrm{b}} \pm 33.04$ & $1.54^{\mathrm{b}} \pm 0.14$ & $10.00^{\mathrm{b}} \pm 0.52$ \\
\hline Freeze-drying & $93.43^{\mathrm{b}} \pm 0.31$ & $119.6^{\mathrm{c}} \pm 11.21$ & $1339.12^{\mathrm{c}} \pm 46.58$ & $5.23^{\mathrm{c}} \pm 0.86$ & $5.86^{\mathrm{c}} \pm 0.36$ \\
\hline
\end{tabular}

Results are means \pm standard deviation. Mean values in the same column designated with different small letters are significantly different $(\alpha=0.05)$

Table 3.

The content of selected ingredients and antioxidant activity of fresh thyme herb and its droughts

\begin{tabular}{lccccc}
\hline & $\begin{array}{c}\text { Dry mass } \\
{[\%]}\end{array}$ & $\begin{array}{c}\text { Chlorophyll } \\
{[\mathrm{mg} / 100 \mathrm{~g} \mathrm{~d} . \mathrm{m} .]}\end{array}$ & $\begin{array}{c}\text { Polyphenols } \\
{[\mathrm{mg} / 100 \mathrm{~g} \mathrm{~d} . \mathrm{m} .]}\end{array}$ & $\begin{array}{c}\text { Ascorbic acid } \\
{[\mathrm{mg} / 100 \mathrm{~g} \mathrm{~d} . \mathrm{m} .]}\end{array}$ & $\begin{array}{c}\text { DPPH IC } \\
{[\mathrm{mg} / \mathrm{ml}]}\end{array}$ \\
\hline Fresh & $9.49^{\mathrm{a}} \pm 0.47$ & $463.19^{\mathrm{a}} \pm 18.45$ & $73.87^{\mathrm{a}} \pm 4.12$ & $41.27^{\mathrm{a}} \pm 1.13$ & $201.5^{\mathrm{a}} \pm 1.56$ \\
\hline Convective drought & $93.57^{\mathrm{b}} \pm 0.17$ & $212.96^{\mathrm{b}} \pm 12.65$ & $1083.09^{\mathrm{b}} \pm 22.64$ & $3.25^{\mathrm{b}} \pm 0.24$ & $10.04^{\mathrm{b}} \pm 0.74$ \\
\hline Freeze-drying & $93.70^{\mathrm{b}} \pm 0,02$ & $71.70^{\mathrm{c}} \pm 5.76$ & $1101.02^{\mathrm{c}} \pm 28.03$ & $10.51 \mathrm{c} \pm 0.58$ & $7.77^{\mathrm{c}} \pm 0.17$ \\
\hline
\end{tabular}

Results are means \pm standard deviation. Mean values in the same column designated with different small letters are significantly different $(\alpha=0.05)$

The results of the conducted research indicate a significant influence of the applied processes on the quantity of released compounds which determines antioxidant activity of herbs. The freeze-drying process caused the release of higher amounts of polyphenols, as compared to convective drying. The results of the chemical composition of the tested herbs were similar to the values received by Kazimierczak et al. [30] and Telesiński [31]. The content of active ingredients in rosemary herb was higher than that of studies conducted by Rusaczonek et al. [2]. Similarly, for convective drought, the polyphenol content exceeded twice the results obtained by Proestos et al. [32]. In contrast, in rosemary subjected to lyophilisation, the polyphenol content was almost two times lower than in the range given by Papageorgiou et al. (4240-6360 mg/100 g d.m.) [5]. The sum of polyphenols for fresh sage was more than twice lower than in studies conducted by Hossain et al. [15] According to
Proestos et al. [32], the polyphenols content for convective droughts was $1560 \mathrm{mg} / 100 \mathrm{~g}$ dry mass, which was slightly higher than that obtained in our research (1159 mg/100 g d.m.). In freeze-dried drought, the content was $1339.22 \mathrm{mg} / 100 \mathrm{~g} \mathrm{~d}$.m. In fresh thyme, the polyphenol content was significantly lower than that obtained by Rusaczonek et al. (35 mg/100 g of raw material) [2]. According to Proestos et al. [32], the polyphenols content obtained in convective drought was $800 \mathrm{mg} / 100 \mathrm{~g} \mathrm{~d} . \mathrm{m}$. and was lower than in our research (1083.09 mg/100 g d.m.). In the lyophilised thyme, the sum of polyphenols was the lowest of the tested spice herbs. In the conducted research, a reverse trend to the results obtained by Couto et al. [33] was observed. Couto et al. [33] found that spray drying of rosemary caused a loss of certain amounts of polyphenols. It might have been related to other parameters of the drying process, mainly high temperatures used during spray drying $\left(140^{\circ} \mathrm{C}\right)$. 
Drying processes have a significant impact on the formation and degradation of compounds. According to Hossain et al. [15], there is the possibility of enzymatic degradation of polyphenols in fresh samples, which leads to reduction in their content. Our research has shown that the drying process has a significant impact on the bioavailability of biologically active compounds. The obtained results of the polyphenol sum content as well as the results of other authors [16, 17], indicate that the polyphenol content was increased due to the release of phenolic antioxidants from the matrix, caused by a destruction of the cell structure as a result of drying (fig. 1).

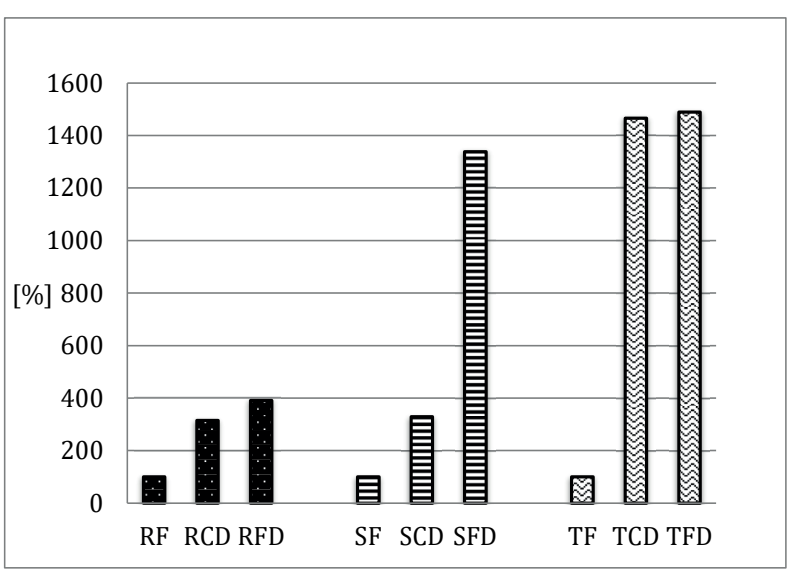

Figure 1. herbs

Changes of polyphenol content after drying of

$\mathrm{RF}$ - rosemary fresh, RCD-rosemary convectional drying, RFD-rosemary freeze drying

SF - sage fresh, SCD-sage convectional drying, SFD- sage freeze drying

TF - thyme fresh, TCD-thyme convectional drying, TFD-thyme freeze drying

In some studies $[2,15,17,34]$, a high correlation between the total polyphenol content and the antioxidant capacity of herbal extracts was indicated. This shows the role of polyphenols in antioxidant properties of herbs. The $\mathrm{IC}_{50}$ parameter, which gives information on the concentration of antioxidant causing a 50\% reduction of DPPH free radical, was calculated. It has been demonstrated that the amounts of dried herbal extracts needed to reduce the radical, are much smaller than those obtained from fresh herbs (tab. 1-3). In studies by Unvera et al. [35], $\mathrm{IC}_{50}$ value for dried rosemary was more than three times lower, as it amounted to $2.373 \mathrm{mg} / \mathrm{ml}$.
In the freeze-drying droughts, the value of the coefficient was at the level of $5.34 \mathrm{mg} / \mathrm{ml}$. For fresh sage and its sublimation drought, the $\mathrm{IC}_{50}$ values were 199.99 and $5.86 \mathrm{mg} / \mathrm{ml}$, respectively (tab. 2). In the case of convective drought, this value reached $10.00 \mathrm{mg} / \mathrm{ml}$ and was over 10 times higher than that obtained by Unvera et al. $(0.810 \mathrm{mg} / \mathrm{ml})$ [35].

Herbs used in the conducted research are traditionally consumed as infusion or additive, and often are added in the form of droughts to various dishes. The obtained data clearly indicate the positive impact of the applied processes on the antioxidant potential of herbaceous plants. The applied drying processes caused not only release of additional active compounds but also the possibility of longer storage under conditions of room temperature, due to its preservation.

The content of vitamin $\mathrm{C}$, in the form of ascorbic acid, in fresh herbs was in the range of $31.5 \mathrm{mg} / 100 \mathrm{~g}$ d.m. in sage to $55.26 \mathrm{mg} / 100 \mathrm{~g}$. d.m. in rosemary. Drying processes significantly reduced its content in all tested samples. In sage, drying processes reduced the amount of ascorbic acid, by $95 \%$ for convective drying and $83 \%$ for the lyophilisate. In the case of rosemary, the observed decrease was $88 \%$ for dried and $79 \%$ for the lyophilisate, while in convective dried thyme, the decrease was $92 \%$ in relation to the initial value, and $74 \%$ for the lyophilisate.

Vitamin C (ascorbic acid) should be consumed daily, preferably in a natural form. Fresh herbs are a great source of this vitamin, while the processing causes its significant losses. It is associated with low durability and susceptibility to the decomposition of ascorbic acid under the influence of many factors, including elevated temperature and the presence of oxygen [36]. The content of ascorbic acid in the studied herbs, both fresh and dried, was in agreement with the values obtained by other authors [32, 37, 38]. Analysis of obtained results indicated that technological processes caused a decrease in the content of ascorbic acid. Similarly, the applied processes adversely affected the content of chlorophyll dyes, causing their degradation. At the same time, it was shown that the convective drying was more beneficial compared to freeze-drying.

Performed research showed that the highest amount of chlorophylic dyes was in fresh raw material (tab. 1-3). The obtained values were similar to the results obtained by other authors [2, 20,23]. The drop in dyes content for droughts was $50 \%$ on average, and in the case of lyophilisates it was significantly higher and amounted to $74 \%$ (thyme), $84 \%$ (sage) and $94 \%$ (rosemary), respectively. The 
amount of chlorophyll in studied herbs was higher than that of chlorophyll $b$. The only exception was fresh thyme.

During drying of the vegetable raw material, degradation of chlorophyll a and b occurs, and thus the colour change [38]. Decomposition of dyes may take place to a greater or lesser extent, depending on the technological parameters of the process used. Figure 2 shows the changes in the content of chlorophyll pigments in studied herbs. Conducted research indicated that changes in the content of chlorophylls significantly depended on the drying method used. In studies of Król and Dadasiewicz [12], freezedrying allowed to preserve green dyes to a greater extent than convective drying. The strongest browning of the herb was found at the highest temperature $\left(60^{\circ} \mathrm{C}\right)$. Lowering of drying temperature limited the loss of chlorophyll dyes caused by thermal degradation. In turn, drying of herbs in natural conditions also caused adverse changes in colour, which, as reported by Arabhosseini et al. [13], may result from the decomposition of chlorophyll due to the duration of this process. A study by Nowacka et al. [14] indicated that as a result of drying with the use of microwaves, a product obtained is more similar to unprocessed raw material than to that after convective drying.

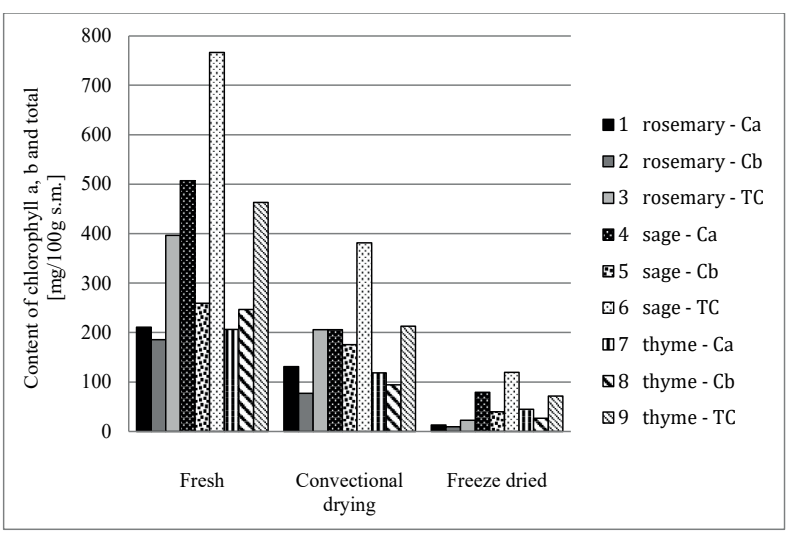

Figure 2.

Changes in the content of chlorophyll dyes: chlorophyll a $(\mathrm{Ca})$, chlorophyll $\mathrm{b}(\mathrm{Cb})$ and total chlorophyll (TC) in the studied spice plants and their convective and freeze-dried droughts

There are many factors that influence the demand for dehydrated herbs. Due to the high content of antioxidant compounds, herbal drought can be used in the production of functional foods. Based on the analyses performed, it was found that technological processes had at the same time positive and negative effects on the content of biologically active ingredients in spice plants. As a result of the convection and sublimation drying processes, losses in the content of vitamin C (74-95\%) and chlorophyll dyes (50-94\%) in relation to the fresh raw material were observed. However, the polyphenol content and antioxidant activity increased. The highest increase in polyphenol content was recorded in case of lyophilised thyme.

The advantages of freeze-drying are high-quality dehydrated products due to the absence of liquid water and the low temperatures required in the process, preservation of constituents as minerals and vitamins, as well as retaining original flavour and aroma. Freeze-drying, therefore, might be regarded as a promising technique for dehydration of thermal-sensitive materials, such as herbs [19]. On the other hand, it is an expensive process, in comparison to convective drying. The results of our research indicate that the use of freeze-drying process is not entirely justified for economic reasons. The decrease in the content of tested active compounds: vitamin $\mathrm{C}$ and chlorophyll was higher in the case of herbs dried by convection, however, it seems that the use of freeze-drying cannot be applicable.

Conflict of interest: Authors declare no conflict of interest.

\section{REFERENCES}

1. Anioł-Kwiatkowska J, Kwiatkowski S, Berdowski W. Rośliny lecznicze. Atlas. Warszawa 1993. [in Polish]

2. Rusaczonek AM, Żebrowska B, WaszkiewiczRobak B, Ślusarczyk E. Evaluation of phenolic compounds content and antioxidant capacity of herbs. Pol J Food Nutr Sci 2007; 57(4):483-488.

3. Chakraborty R, Dey T. Drying protocols for traditional medicinal herbs: a critical review. Int J Eng Technol Manag Appl Sci 2016; 4(4):31-319.

4. Boruch M, Król B. Procesy technologii żywności. PŁ Łódź 1993. [in Polish]

5. Kowalska K, Olejnik A. Rozmaryn - roślina zielarska o potencjale terapeutycznym. Post Fitoter 2010; 2:114-122. [in Polish] 
6. Jadczak D, Grzeszczuk M. Szałwia w kuchni. Panacea 2005;13(4):24-26. [in Polish]

7. Ożarowski A, Jaroniewski W. Rośliny lecznicze i ich praktyczne zastosowanie. Warszawa 1987. [in Polish]

8. Papageorgieu V, Mallouchos A, Komaitis M. Investigation of the antioxidant behavior of air- and freeze-dried aromatic plant material in relation to their phenolic content and vegetatice cycle. J Agric Food Chem 2008; 56:5743-5752.

9. Rząca M, Witrowa-Rajchert D. Zmiany aktywności przeciwrodnikowej i zawartości polifenoli w suszu jabłkowym uzyskanym przy wykorzystaniu promieniowania podczerwonego. Żywność. Nauka. Technologia. Jakość 2009; 1(62):99-108. [in Polish]

10. Manzocco L, Calligaris S, Mastrocola D, Nicoli M.C, Lerici C.R. Review of non-enzymatic and antioxidant capacity in processed foods. Trends Food Sci Technol 2001; 11:340-346. doi: http:// dx.doi.org/10.1016/S0924-2244(01)00014-0

11. Nowacka M, Witrowa-Rajchert D, Strachota W, Sobczak E. Wybrane właściwości promiennikowo-konwekcyjnych suszy marchwi i ziemniaka. Acta Agrophys 2010; 16(1):127-136. [in Polish].

12. Król B, Kiełtyka-Dadasiewicz A. Wpływ metody suszenia na cechy sensoryczne oraz skład olejku eterycznego tymianku właściwego (Thymus vulgaris L.). Żywność. Nauka. Technologia. Jakość 2015;4(101):162-175. doi: http://dx.doi. org/10.15193/ZNTJ/2015/101/064

13. Arabhosseini A, Padhye S, Huisman W, van Boxtel A, Müller J. Effect of drying on the color of tarragon (Artemisia dracunculus L.) leaves. Food Bioprocess Tech 2011;4(7):1281-1287. doi: http:// dx.doi.org/10.1007/s11947-009-0305-9

14. Nowacka M, Śledź M, Wiktor A, Witrowa-Rajchert D. Fizyczne i chemiczne właściwości produktów spożywczych suszonych z wykorzystaniem mikrofal. Żywność. Nauka. Technologia. Jakość 2012; 85(6):5-20.

15. Hossain MBC, Barry-Ryan A, Martin-Diana B, Brunton NP. Effect of drying method on the antioxidant capacity of six Lamiaceae herbs. Food Chem 2001; 123(1):85-91. doi: https://doi. org/10.1016/j.foodchem.2010.04.003
16. Arslan D, Özcan MM, Mengeș HO. Evaluation of drying methods with respect to drying parameters, some nutritional and colour characteristics of peppermint (Mentha xpiperita L.). Energ Convers Manage 2010; 51:2769-2775. doi: https://doi. org/10.1016/j.enconman.2010.06.013

17. Chumroenphat T, Khanpromand I, Butkhup L. Stability of phytochemicals and antioxidant properties in ginger (Zingiber officinale Roscoe) rhizome with different drying methods. J Herbs Spices Med Plants 2011;17:4,361-374. doi: http:// dx.doi.org/10.1080/10496475.2011.629776

18. Mehrnia MA, Bashti A, Nasab HM. Chemical composition and antioxidant properties of some species of Lamiaceae family from Iran. JMPB 2017; 2:125-130.

19. Marques LG, Ferreira MC, Freire JT. Freeze-drying of acerola (Malpighia glabra L.). Chem Eng Process 2007; 46(5):451-457. doi: https://doi.org/10.1016/j.cep.2006.04.011.

20. Rząca M, Witrowa-Rajchert D. Wybrane właściwości fizyczne suszonych produktów roślinnych. In: Dobrzański B, Mieszkalski L (eds.). Physical properties of dried raw materials and food products. Lublin 2007, p. 35-43.

21. Stępień B. Wpływ suszenia konwekcyjnego na wybrane cechy mechaniczne i reologiczne korzenia pietruszki. Inżynieria Rolnicza 2008; 103(5):267-273. [in Polish]

22. Ratti C. Hot air and freeze drying of high value foods. J Food Eng 2001; 49:311-319.

23. Rząca M, Witrowa-Rajchert D. Suszenie żywności w niskiej temperaturze. Przemysł Spożywczy 2007, 4, 30-35. [in Polish]

24. PN-EN 12145:2001 Oznaczenie zawartości suchej masy metodą wagową. Przetwory owocowe i warzywne. [in Polish]

25. Singleton VL, Rossi JA. Colorimetry of total phenolics with phosphomolybdic-phosphotungstic acid reagents. Am J Enol Viticult 1965; 16:144158.

26. Yen GC, Chen HY. Antioxidant activity of various tea extract in relation to their antimutagenicity. J Agric Food Chem 1995; 43(1):27-32. 
27. PN-A-04019:1998. Produkty spożywcze - Oznaczanie zawartości witaminy C. 1998. [in Polish]

28. Klimczak J. Chlorofile. In: Michałowski S. (ed.). Technologia chłodnictwa żywności. Składniki pokarmowe i kontrola ich przemian. Łódź 1995. [in Polish]

29. Khorshidi J, Mohammadi R, Fakhr TM, Nourbakhsh $\mathrm{H}$. Influence of drying methods, extraction time, and organ type on essential oil content of rosemary (Rosmarinus officinalis L.). Nat Sci 2009; 7(11):42-44.

30. Kaźmierczak R, Hallman E, Sokołowska O, Rembiałkowska E. Zawartość związków bioaktywnych w roślinach zielarskich $\mathrm{z}$ uprawy ekologicznej i konwencjonalnej. J Res Appl Agric Eng 2011; 56(3):200-205. [in Polish]

31. Telesiński A, Grzeszczuk M, Jadczak D, Wysocka G, Onuszko M. Ocena zmian zawartości azotanów (V) w wybranych ziołach przyprawowych w zależności od sposobu ich utrwalania i czasu przechowywania. Żywność. Nauka. Technologia. Jakość 2013; 90(5):168-176. [in Polish]

32. Proestos C, Lytoundi K, Mawromelanidou OK, Zoumpoulakis P, Sinanoglou V. Antioxidant capacity of selected plant extract and their essential oil. Antioxidants 2013; 2:11-22. doi: http://dx.doi. org/10.3390/antiox2010011
33. Couto RO, Conceição EC, Chaul LT, Oliveira EMS, Martins FS, Bara MTF, et al. Spray-dried rosemary extracts: Physicochemical and antioxidant properties. Food Chem 2012; 131:99-105. doi: https://doi.org/10.1016/j.foodchem.2011.08.036

34. Oktay M, Gulcin I, Kufrevioglu OI. Determination of in vitro antioxidant activity of fennel (Foeniculum vulgare) seed extracts. LWT - Food Sci Technol 2003; 36:263-271. doi: http://dx.doi. org/10.1016/S0023-6438(02)00226-8

35. Unver A, Arslan A, Ozcan MM, Akbulut M. Phenolic content and antioxidant activity of some spices. World Appl Sci J 2009; 6(3):373-377.

36. Mazurek A, Pankiewicz U. Changes of dehydroascorbic acid content in relation to total content of vitamin $\mathrm{C}$ in selected fruits and vegetables. Acta Sci Pol Hort 2012; 11(6):169-177.

37. Kaźmierczak R, Hallman E, Ardasińska B, Łoś B. Wpływ ekologicznego i konwencjonalnego systemu uprawy na zawartość związków fenolowych w roślinach zielarskich. J Res Appl Agricult Eng 2012; 57(3):198-203.

38. Śledź M, Witrowa-Rajchert P. Składniki biologicznie czynne w suszonych ziołach - czy ciągle aktywne? Kosmos. Problemy Nauk Biologicznych 2012; 298(2):319-329. [in Polish] 